\title{
Does the characteristics of regional government and complexity affect on the disclosure regional financial statements?
}

\author{
Pancawati Hardiningsih ${ }^{1 *}$, Indira Januarti ${ }^{2}$, Ceacilia Srimindarti ${ }^{3}$, Rachmawati Meita Oktaviani ${ }^{4}$ \\ ${ }^{1}$ Ph.D Student at Diponegoro University; Department of Accounting, Stikubank University, Indonesia \\ 2 Department of Accounting, Diponegoro University, Indonesia \\ ${ }^{3,4}$ Department of Accounting, Stikubank University, Indonesia \\ ${ }^{*}$ Corresponding author email: pancawati@edu.unisbank.ac.id
}

A R TICLE IN F O

Article history:

Available online

Keywords:

government characteristics,

complexity, RGFS disclosure

DOI:

https://doi.org/10.20885/jaai.vol23. iss2.art5
A B S T R A C T

This study aims to analyze the factors that influence the level disclosure of Regional Government Financial Statements. The sample of this study were 101 local government financial statements at Indonesia in 2016-2018. This study uses multiple regression analysis. These results provide that regional wealth, government size, and the number of regional apparatus working units had a significant positive effects on the level of disclosure of Regional Government Financial Statements (RGFS). Whereas the level of dependency and the legislative had no effect on the level of disclosure of RGFS. Not all regional governments make disclosures based on RGFS by referring to new Government Regulation. This study uses a disclosure index that is considered to have an equal weight, and inappropriate use of proxies results in inappropriate analysis of the results showing the performance of local governments. It is expected that the future study is able to use the level of disclosure required RGFS based on the latest GAS accrual basis that began to be applied by all local governments in 2015, then need to give weight to items disclosed in the financial statements.

\section{Introduction}

Public sector accounting reform marked the issuance of Government Regulation (GR) Number 71 year 2010 replacing Government Regulation Number 24 year 2005 concerning Accrual-based Government Accounting Standards (GAS) to the momentum of accounting development in Indonesia after more than 60 years the accounting recording system of the government used a cash basis (Heriningsih \& Rusherlistyani, 2013). This reform is a concrete effort in realizing good governance, and increasing transparency and accountability in the management of the central government and regional government (pemda) finances. This condition is also supported by Law No. 32/2004 that provinces, regencies and municipalities are required to prepare financial reports (Suhardjanto \& Yulianingtyas, 2011). The compiled government financial reports, therefore, must follow GAS in accordance with PP Number 71year 2010. This is also confirmed in the statement of Law Number 17 of 2003 concerning State Finance and Law Number 1 of 2004 concerning State Treasury which also mandates the preparation of reports central government and regional government responsibilities must be in accordance with GAS.

Central government and local government financial reports are used by investors, employees, financial institutions, government and the community for economic decision making. The quality of decision making is influenced by the quality of annual financial statements. Therefore, the presentation of financial statements must attach sufficient disclosures to be understood and must not cause misinterpretation. Transparency and accountability in government financial are an important element in the creation of good governance (Sumartono \& Pasolo, 2019). Disclosure of this information also includes adherence to the budget Government Accounting Standards Guidelines (GASG) Number 1 Paragraph 24. As for the disclosure and explanation for some items that are not presented in the financial statements can be presented in Notes to the Financial Statements (Syafitri, 2012; and Fitri, 2011). To find out the government's obedience in preparing financial statements against GAS, this study uses mandatory disclosure which is done by comparing the disclosures in the Regional Government Financial Statements (RGFS) with those that should be disclosed in GAS so that it measures compliance better compared to disclosures.

In line with the implementation of broad, real and responsible regional autonomy, it is necessary to have the authority and ability to explore regional financial resources. Local Own Revenue (LOR) is the main source of 
the region which is obtained from taxes and user fees that come from the local community (Prakosa, 2004). Thus, the greater the LOR the better the level of regional financial independence is, so the local government will be encouraged to make financial statement disclosure in full to be more transparent and accountable (Dwirandra, 2008). Khasanah and Rahardjo (2014); and Hendriyani and Tahar (2015) found that LOR had no influence on the level of RGFS disclosure. On the other hand, Hilmi and Martani (2012); Setyaningrum and Syafitri (2012); and Feriyanti et al. (2015) shows that the level of local government wealth proxied by the LOR has a significant positive effect on the level of disclosure of the provincial government's financial statements.

The limited LOR obtained by the regional government will increase the dependence on the assistance from the central government is still large so as to make the central government to restrict operations and ask for more disclosure to monitor the performance of local governments. In line with the opinion of Heriningsih and Rusherlistyani (2013) that the level of dependency shows how much the local government runs a work program that has been designed with the help of the central government. As a form of accountability for the use of funds, local government are demanded to be more transparent and accountable in the management of regional finances in order to realize the public, central and provincial government entrust that the funds is not misused. Feriyanti et al. (2015) found that the level of dependence of municipality had a positive and significant effect on the level of RGFS disclosure. However, Hilmi and Martani (2012); Heriningsih and Marita (2013); Khasanah and Rahardjo (2014); and Cristiana and Maryono (2016) found that the level of dependency did not affect the level of RGFS disclosure. On the other hand, Hendriyani and Tahar (2015) found that the level of dependency had a negative influence on the level of RGFS disclosure.

Mahsum et al. (2006) explained that total assets are economic resources that are controlled and/or owned by the government as a result of past events for future economic benefits that are expected to be obtained, both by the government and the community. Assets can be measured in units of money, including non-financial resources needed by service providers for the general public and for the maintenance of resources for historical and cultural reasons. Large and complex total assets will require good asset management so more detailed disclosures are needed regarding asset maintenance and management. The greater the number of assets shows the size of the regional government is getting richer, the more resources are used so that more disclosure is needed. Patrick (2007) and Khasanah and Rahardjo (2014) show that variable size proxied by total assets has a positive and significant effect on the completeness of RGFS disclosures. On the contrary, Cristiana and Maryono (2016) found that total assets have a negative influence on the completeness of RGFS disclosures. Different results by Hilmi and Martani (2012); and Heriningsih and Rusherlistyani (2013) that total assets do not affect the level of RGFS disclosure.

The Number of Regional (Apparatus) Working Units (R(A)WU) illustrates the number of functions that are the priorities of regional governments in developing regions. The more government priorities the government has, the more complex the government will be. The greater number of R(A)WUs in a local government means that the problem is more complex, so that the disclosure of the financial statements of regional governments is more detailed. This shows that the more functional differentiation in local government, the more ideas, information and innovations available (Mandasari, 2009). Hilmi and Martani (2012); Setyaningrum and Syafitri (2012); and Hendriyani and Tahar (2015) found that the number of R(A)WU (functional differentiation) had no effect on the level of RGFS disclosure. Whereas Khasanah and Rahardjo (2014) found that the number of R(A)WU has a negative effect on the level of RGFS disclosure. However, Feriyanti et al. (2015) and Cristiana and Maryono (2016) found the number of R(A)WUs had a significant positive effect on the level of RGFS disclosure.

The Indonesian government system, which acts as a legislative body, is the Regional Representative Council (RRC). The RRC as a community representative has a supervisory function, which is to control the running of the government so that it is always in line with the aspirations of the people rather than as a legislative body in the true sense and oversees the implementation and reporting of regional government financial information in order to create a transparent and accountable atmosphere. The main function of the RRC is to control the running of the government in the regions, while with regard to the legislative function, the position of the RRC is not a dominant actor. The dominant power holder in the legislative field remains the Governor or Regent/Mayor. That is, the RRC only acts as a controlling or controlling body that can approve or even reject it altogether or approve with certain changes, and occasionally can propose its own initiative to submit a draft Regional Regulation. So the role and position of the RRC is strategic in controlling regional financial policies economically, efficiently, effectively, transparently, and accountably (Medynatul, 2017). Thus, the greater the number of legislative members is expected to be more intensive in controlling local government finances. As a consequence, regional governments will be more responsible for disclosing accounting information in accordance with GAS provisions.

Suhardjanto and Yulianingtyas (2011); and Setyaningrum and Syafitri (2012) found that the number of legislative members or RRC has a positive effect on the level of RGFS disclosure. Likewise, Giligan and Matsusaka (2001) found that legislative size had an effect on fiscal policy in the United States government in the early mid- 
20th century. Thus, the increasing number of RRC members was expected to be more stringent in monitoring the regional governments so that they were demanded to be more obedient in disclosing RGFS according to GAS.

The reason RGFS was chosen was because of the importance of the level of disclosure of government financial statements to achieve government transparency and accountability. Hilmi and Martani (2012) found that the province with low disclosure rates was West Papua. Likewise, Liestiani and Martani (2012) shows that the average level of compulsory disclosure of RGFS is $35.45 \%$, and Suhardjanto and Lesmana (2010) is $51.56 \%$. This shows that the regional government has not fully disclosed the required disclosure items in its financial statements. The existence of disclosure that is still low will affect the opinion given by the Supreme Audit Board (SAB). From the explanation above, it can be formulated that how much influence the regional wealth, the level of regional dependence, government size, $\mathrm{R}(\mathrm{A}) \mathrm{WU}$, and legislative size on the level of Disclosure of RGFS. Thus this study aims to analyze the effect of regional wealth, the level of regional dependence, government size, R(A)WU, and legislative size on the level of RGFS Disclosure.

The novelty of this study is carried out by including the legislative size as a control variable. This is done because with the control variables, the results of the analysis can better explain the phenomenon optimally because other variables also influence the dependent variable to be interrupted. So it has a function to neutralize its influence on the dependent variable. The second reason, the analysis will have a higher statistical power.

This study is expected to have a contribution to the regional government as an evaluation material in order to improve the accountability and transparency of local government financial reports. For the community as a means of information about accountability and transparency that occurs in Indonesia. In addition, this study also contributed to the stewardship theory that regional wealth, government size, and the number of R(A)WU had a positive effect on the level of RGFS disclosure, so the findings support the stewardship theory.

\section{Literature Review}

\section{Stewardship Theory}

Stewardship theory approach that describes a situation where the government (steward) is not motivated by individual goals such as material and money but rather is aimed at the main outcome objectives for the benefit of the organization that is providing public services (Godfrey et al., 2010). This theory is more related to the form of accountability carried out by the local government (steward) to the community (principal) in carrying out the mandate. Because psychologically and sociologically the recipients of the mandate (steward) are motivated to act according to the wishes of the trustee (principal) that is making accountability in the form of financial statements and disclosures. They are believed to have the same goals as the goals of the organization. This causes stewards to have high loyalty to the organization (Khasanah \& Rahardjo, 2014).

Communities represented by the council will directly conduct oversight of government performance, requiring information that can support the process of monitoring government performance. As a form of responsibility, the government must disclose financial reports in accordance with applicable regulations (Waliyyani \& Mahmud, 2015).

The relationship that exists between the local government (steward) with the community (principal) on the basis of human nature. The community believes that the government will be responsible for fulfilling their rights and acting according to obligations based on relevant local regulations. Based on this theory the government is believed to be the public as a party that can be trusted, has high integrity and honesty (Mandasari, 2009). So that they can carry out their duties as mandated. Integrity and honesty are intrinsic factors that cannot be measured or assessed, but the rewards in stewardship theory include growth opportunities, self-actualization and membership (Godfrey et al., 2010).

The government as a party that has a lot of information will be responsible for the trust that has been given by the people who have the awareness to continue to realize transparency and accountability. The existence of this awareness is necessary to actualize themselves as obedient government employees must carry out the mandate to carry out accountability through the presentation of financial statements in accordance with GAS. Stewardship theory seeks to understand the good quality of services that must be owned by local governments so as to change the perspective of the relationship between "principals" and "agents" (Schillemans, 2013).

\section{Hypothesis}

Local government wealth illustrates the level of regional prosperity (Munoz \& Bolivar, 2015). Local government wealth is proxied by LOR. The main sources of LOR are regional taxes and levies from local communities. The greater the LOR shows the greater resources owned by the region. Thus, the greater the LOR, the higher the 
community participation in paying regional taxes and fees will be. This condition will encourage regional governments to make complete disclosures in their financial statements to create transparency and accountability.

Stewardship oriented theory, that local governments try to show the responsibility of its performance well through the results of a large wealth and a lot of resources so that they try to express it better in their financial statements. An increase in disclosure is expected to reduce information asymmetry between the government and the community. Setyaningrum and Syafitri (2012); Liestiani and Martani (2012); Feriyanti et al. (2015); and Cristiana and Maryono (2016) found that LOR/regional wealth had a positive and significant effect on the level of disclosure of Provincial RGFS. Likewise, Hilmi and Martani (2012) shows that the level of regional wealth has a significant positive effect on the level of disclosure of Provincial RGFS. From the description above, the following hypothesis is formulated:

H1: Local government wealth has a positive effect on the level of RGFS disclosure.

The higher transfer funds received by local governments, shows a high degree of dependence on other sources of funds to finance their apparatus. Local governments that have a high level of dependence on central government funding sources, then these regions have pressure to disclose more information. The amount of transfer funds provided by the central government has consequences in the form of monitoring from the center to the regions related to the government's flexibility in using the transfer funds. The greater of the dependency level, the greater of the disclosure level that must be done by local governments.

Referring to the stewardship theory that accountability for the use of transfer funds is an effort to steward awareness in carrying out its mandate role, responsible for disclosing transparent and accountable financial statements in the use of transfer funds from the central government. Disclosure of these financial statements as an effort to reduce information asymmetry and to realize public confidence in both the community and the central or provincial government that funds are not misused. Pitman and Groff (2004); Ryan et al. (2002); Martani and Lestari (2010); Mustikarini and Fitriasari (2012); and Feriyanti et al. (2015) found that the level of dependency of the municipality was positively and significantly related to the level of RGFS disclosure. Due to the high dependency, it is possible that the government is limiting regional government operations and requesting more disclosure to monitor the work of regional governments with restrictions on operating funds.

H2: The level of dependence has a positive effect on the level of Provincial RGFS disclosure.

Assets are resources used by entities in carrying out operational activities, because assets represent economic resources that are controlled and /or owned by the regional government as a result of past events and from which future economic benefits are expected to be obtained. Owned assets are also a set of components of financial statements. The greater number of assets, the greater resources that can be used to make greater disclosures.Large and complex total assets will require good asset management, so more disclosure is needed related to asset maintenance and management. Regions that have a larger total asset size will have greater demands to disclose more in the RGFS.

Refer to stewardship theory that local government as a steward will try its best to run the government well as a form of accountability to the community. So that local governments in carrying out the duties and responsibilities of regional financial management accountably and transparently in accordance with GAS. Therefore local governments that have large and complex total assets need to disclose more in detail in the financial statements as required in GAS given that each asset has different characteristic specifications. Patrick (2007) and Khasanah and Rahardjo (2014) show that variable size which is proxied by total assets has a positive and significant effect on the completeness of RGFS disclosure.

H3: Governments size have a positive effect on the level of RGFS disclosure

Regional financial independence shows the ability of regional governments in $R(A) W U$ is an accounting entity that is obliged to record transactions that occur within the regional government. The number of R(A)WUs illustrates the number of functions that are the priorities of regional governments in developing regions. The more functions that are prioritized by the regional government, the more complex the government will carry out its activities. The greater the $\mathrm{R}(\mathrm{A}) \mathrm{WU}$ owned means the more complex the government is. The more complex government, the greater the level of disclosure will be by Hilmi and Martani (2012).

Focusing on stewardship theory that the more the number of $\mathrm{R}(\mathrm{A}) \mathrm{WU}$ shows the complex differentiation of the local government, the more information must be disclosed as an effort to reduce information asymmetry to the public. The more $\mathrm{R}(\mathrm{A}) \mathrm{WU}$ in local government, the more ideas, information and innovations available regarding disclosure (Mandasari, 2009) and (Khasanah \& Rahardjo, 2014). This condition requires regional governments to comply with GAS in disclosing financial statements in more detail. Thus the community will judge that the steward can carry out the mandate properly. Then the sense of public trust in honesty and integrity in stewards is increasing. 
Patrick (2007) and Cristiana and Maryono (2016) show that LGs with higher levels of functional differentiation tend to make higher disclosures. From the description above, the following hypotheses are formulated: H4: Number of R(A)WU positively influences the level of disclosure of Provincial GFS

Referring to the study of theory and the hypotheses development, research model can be seen in figure 1.

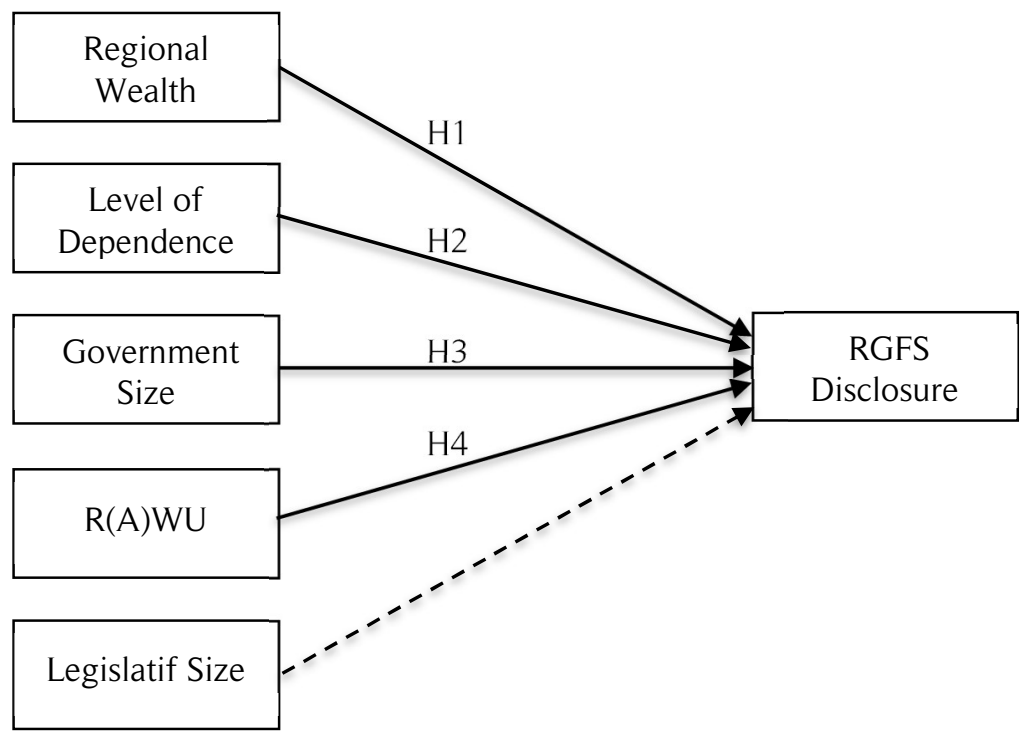

Figure 1. Research Model

\section{Research Method}

The population of this study used RGFS from 34 provincial governments in Indonesia in the 2016-2018 period audited by the Supreme Audit Board (SAB) sourced from Indonesia SAB with a total of 102 RGFS. While the selected sample is the entire population except for one financial statement that was not included in the sample, namely the province of North Kalimantan because of the unavailability of data.

The type of data used is quantitative data, i.e. data measured on a numerical scale (Sekaran \& Bougie, 2010). The data source of this study are RGFS of all provinces in the 2016-2018 fiscal year audited by SAB. Whereas information on the number of legislative was obtained from Statistic Central Body (SCB) in 2016, 2017 and 2018 which was obtained in the SCB library. Meanwhile, other data not found in RGFS can be obtained from SCB and the official website of each province.

The level of Provincial GFS Disclosure is the comparison between disclosures that have been presented in the Provincial GFS with disclosures that should be presented in Notes to Financial Statements (CaLK) according to SAP. The level of Provincial GFS disclosure will illustrate how much the level of disclosure made by the Provincial Government compared to the mandatory disclosures that should be presented in the NtFS according to GAS. The level of disclosure in this study uses a scoring system that is by making a disclosure checklist that is required under GAS Government Regulation No. 71 of 2010. In this study using a disclosure index as in Suhardjanto and Lesmana (2010) which contains 46 disclosure items according to GASG No. 5 up to Number 9 and plus 7 mandatory disclosure items in the NtFS so there are a total of 53 disclosure items.

Regional wealth illustrates the level of regional prosperity. Regional prosperity is seen in the LOR. LOR is sourced from local taxes, regional levies, profits from regionally owned enterprises (BUMD), and other legitimate local revenue. LOR aims to give authority to regional governments to fund the implementation of regional autonomy in accordance with regional potential as a manifestation of decentralization. Regional wealth is proxied by LOR as it was done Hendriyani and Tahar (2015); Liestiani and Martani (2012); and Syafitri (2012).

The level of dependency is how much the regional government runs a work program that has been designed with the assistance of the Central Government (CG) (Heriningsih \& Rusherlistyani, 2013). Dependency is described in the General Allocation Fund (GAF) given by the provincial government. GAF is a transfer that is general in nature from the provincial government to regional governments as an effort to overcome horizontal inequality with the main objective of equitable distribution of financial capacity between regions (Serrano-Cinca et al., 2009). Proxy of dependent variable as in the research of Gore (2014); Hilmi and Martani (2012); Syafitri (2012); Sudarsana and Rahardjo (2013), namely GAF/Total Revenue. 
Government Size is the level of regional development expressed by the total assets. The greater the total assets, the greater the size of the area. The greater the assets, the greater the invested capital.Total assets are economic resources controlled and/or owned by the government as a result of past events and from which future economic and/or social benefits are expected to be obtained by both the government and the community, and can be measured in monetary units, including non-financial resources needed to provide services to the general public and resources maintained for historical and cultural reasons. Proxies used by regional government varies in sizes and variables as done by Gore (2014); Suhardjanto and Lesmana (2010); Hilmi and Martani (2012), and Syafitri (2012) are total assets.

Legislative Size is the Regional People's Representative Council (RRC). The RRC as a community representative has a supervisory function, which is to control the running of the government so that it always matches the aspirations of the community and oversees the implementation and reporting of regional government financial information in order to create a transparent and accountable government. The legislative size in this study acts as the control and proxy variable used as in the study of Martinsen and Jorgensen (2010); and Syafitri (2012), namely the number of RRC members.

$\mathrm{R}(\mathrm{A}) \mathrm{WU}$ is an accounting entity that is a unit in the government that manages the budget, wealth, and the obligation to hold accounting and present financial statements. The greater the R(A)WU owned means the more complex the government. R(A)WU variables are measured as in the study of Suhardjanto and Lesmana (2010); Hilmi and Martani (2012); Syafitri (2012); and Khasanah and Rahardjo (2014), that is, using a total of all R(A)WUs contained in the regency/municipality of the Regional Government.

The analysis technique used to test the hypothesis of this research model is multiple linear regression with the following model equations:

RGFS-D $=\alpha+\beta_{1} R W+\beta_{2} \operatorname{LoD}+\beta_{3} G S+\beta_{4} R(A) W U+\beta_{5} L+\varepsilon$

Information:

RGFS-D = Province Government Finansial Statement-Disclosure

$\alpha=$ Constant

$\beta=$ Regression coefficient

RW $=$ Regional Wealth

LoD $=$ Level of Dependent

$\mathrm{GS} \quad=$ Goverment Size

$\mathrm{R}(\mathrm{A}) \mathrm{WU}=$ Regoinal (Apparatus) Work Unit

LS $=$ Legislatif Size

$\varepsilon \quad=$ Eror

\section{Results and Discussion}

Descriptions of 101 RGFSs for the 2016-2018 fiscal year that were used in the study in Table 1.

Table 1. Descriptive Statistics

\begin{tabular}{lcrrrr}
\hline & N & Minimum & Maximum & Mean & Std. Deviation \\
\hline RGFS - D & 101 &, 41509 &, 71698 &, 5395106 &, 06693079 \\
Regional Wealth & 101 & 235369 & 6806346 & 1352494,83 & 1272557,557 \\
Legislative & 101 & 35 & 106 & 63,28 & 20,243 \\
Level of Dependence & 101 &, 10441 &, 87434 &, 4470727 &, 18434844 \\
R(A)WU & 101 & 22 & 69 & 43,25 & 8,681 \\
GS & 101 & 12,06 & 14,63 & 12,9395 &, 46303 \\
\hline
\end{tabular}

Source: secondary data processed 2019

Table 1 shows the results of descriptive statistical testing of 101 RGFS Provincial Governments in Indonesia. The minimum value of represents the disclosure of RGFS from South Sumatra province and the maximum value of the RGFS disclosure from Aceh province. This condition shows that overall RGFS disclosure in the provincial government is still relatively low.

The minimum value of dependency from the province of West Java and the maximum value level of dependency from the province of Aceh. Such conditions indicate that the overall level of dependence is relatively low. 
The minimum value of government size comes from the province of West Sulawesi and the maximum value total assets from the province of Jakarta special area of the capital city. This condition as a whole shows that the assets owned by the provincial government are quite large.

The minimum and maximum values of the R(A)WU comes from the North Kalimantan province and the East Java province. Overall the number of $\mathrm{R}(\mathrm{A}) \mathrm{WU}$ s owned by the provincial government is large, which means quite diverse differentiation.

The minimum value of regional wealth from the province of South Sumatra and a maximum value from the province of Aceh and Jakarta special area of the capital city. Such conditions indicate that provincial government LOR is still quite low.

The legislative minimum value from the province of North Kalimantan and Jakarta special area of the capital city province with a maximum legislative value. Such conditions indicate the provincial government legislative is still quite high. Table 2 shows the pearson bivariate correlation.

Table 2. Correlations

\begin{tabular}{|c|c|c|c|c|c|c|c|}
\hline & & $\begin{array}{c}\text { Regional_ } \\
\text { Wealth }\end{array}$ & $\begin{array}{c}\text { Level_of_De } \\
\text { pendence }\end{array}$ & $\begin{array}{c}\text { Government } \\
\text { Size }\end{array}$ & $\mathrm{R}(\mathrm{A}) \mathrm{WU}$ & $\begin{array}{c}\text { Legislatif_Si } \\
\text { ze }\end{array}$ & $\begin{array}{c}\text { RGFS_Disc } \\
\text { losure }\end{array}$ \\
\hline \multirow[t]{3}{*}{ Regional_Wealth } & $\begin{array}{l}\text { Pearson } \\
\text { Correlation }\end{array}$ & 1 & ,279 &, 327 &, $637^{*}$ &, $470^{*}$ &, $641^{*}$ \\
\hline & Sig. (2-tailed) & & ,123 & ,059 & ,035 & ,045 & ,032 \\
\hline & $\mathrm{N}$ & 101 & 101 & 101 & 101 & 101 & 101 \\
\hline \multirow[t]{3}{*}{$\begin{array}{l}\text { Level_of_Depend } \\
\text { ence }\end{array}$} & $\begin{array}{l}\text { Pearson } \\
\text { Correlation }\end{array}$ & ,279 & 1 &, $512^{* *}$ &, $506^{* *}$ &, $727^{* *}$ & ,396* \\
\hline & Sig. (2-tailed) & ,123 & & ,002 & ,002 & ,000 & 021 \\
\hline & $\mathrm{N}$ & 101 & 101 & 101 & 101 & 101 & 101 \\
\hline \multirow[t]{3}{*}{ Government_Size } & $\begin{array}{l}\text { Pearson } \\
\text { Correlation }\end{array}$ & ,327 &, $512^{* *}$ & 1 &, $429^{*}$ & ,611 ${ }^{*}$ & ,230 \\
\hline & Sig. (2-tailed) & ,059 & ,002 & & ,048 & ,036 & 191 \\
\hline & $\mathrm{N}$ & 101 & 101 & 101 & 101 & 101 & 101 \\
\hline \multirow[t]{3}{*}{$R(A) W U$} & $\begin{array}{l}\text { Pearson } \\
\text { Correlation }\end{array}$ &, $637^{*}$ &, $506^{* *}$ &, $429^{*}$ & 1 &, $660^{* *}$ & 678 \\
\hline & Sig. (2-tailed) & ,035 & ,002 & ,048 & & ,000 & ,007 \\
\hline & $\mathrm{N}$ & 101 & 101 & 101 & 101 & 101 & 101 \\
\hline \multirow[t]{3}{*}{ Legislatif_Size } & $\begin{array}{l}\text { Pearson } \\
\text { Correlation }\end{array}$ & ,470* &, $727^{* *}$ &, $611^{*}$ &, $660^{* *}$ & 1 & 299 \\
\hline & Sig. (2-tailed) & ,045 & ,000 & ,036 & ,000 & & ,086 \\
\hline & $\mathrm{N}$ & 101 & 101 & 101 & 101 & 101 & 101 \\
\hline \multirow[t]{3}{*}{ RGFS_Disclosure } & $\begin{array}{l}\text { Pearson } \\
\text { Correlation }\end{array}$ &, $641^{*}$ & ,396* & ,230 &, $678^{*}$ & 299 & 1 \\
\hline & Sig. (2-tailed) & ,032 & 021 & 011 & ,007 & ,086 & \\
\hline & $\mathrm{N}$ & 101 & 101 & 101 & 101 & 101 & 101 \\
\hline
\end{tabular}

$* *$. Correlation is significant at the 0.01 level (2-tailed).

*. Correlation is significant at the 0.05 level (2-tailed).

Based on Table 2, the significant value is known (2-tailed) between regional_wealth and RGFS_disclosure at $0.032<0.05$, which means there is a strong correlation between regional_wealth variables and RGFS_disclosure. Likewise for the legislative_size variable, the R(A)WU variable has a significant correlation with RGFS_disclosure at the 0.05 level of 0.045 and 0.035 , respectively. This relationship is considered quite strong. Similar conditions are also found in the $\mathrm{R}(\mathrm{A}) \mathrm{WU}$ variable with government size variable; legislative size variable with government_size has a strong correlation respectively 0.048 and 0.036 . While the correlation between government_size variables with level_of_dependence and R(A)WU with level_of_dependence also has a fairly strong relationship with the same sig (2-tailed) that is equal to $0.002<0.01$. Similar conditions also exist in the legislative size variable with level of dependence variable and the relationship between the legislative size variable and the $\mathrm{R}(\mathrm{A}) \mathrm{WU}$ variable also has a strong relationship with the same sig (2-tailed) at $0,000<0.01$. Based on Table 3, the regression model equation can be formulated as follows:

Lv. of RGFS-D = 1.089E-15 + 0.223RW + 0.269GS + 0.226LS+ 0.170LD + 0.224R(A)WU

Table 3 shows in the regional wealth value of sig. amounted to 0.048 which can be concluded that regional wealth affects the level of RGFS disclosure (H1 supported). Level of dependency value sig. of 0.180 showed that 
the level of dependency has no effect on the level of RGFS disclosure (H2 not supported). Whereas the government size sig. of 0.028 can be concluded that the government size has a positive effect on the level of RGFS disclosure (H3 supported). Likewhise R(A)WU sig. of 0.047 showed that the R(A)WU has a positive effect on the level of RGFS disclosure (H4 supported). While the value legislative size sig. of 0.049 showed that the legislative size has a role as a control variable proven to affect the level of RGFS disclosure.

Table 3. Hypothesis Testing

\begin{tabular}{lll}
\hline \multicolumn{2}{l}{ Variabel Beta Coefficients Significant Result } \\
\hline (Constant) & $1,089 \mathrm{E}-15$ & \\
Regional Wealth & .223 & $.048 \mathrm{H}_{1}$ Supported \\
Goverment Size & .269 & $.028 \mathrm{H}_{3}$ Supported \\
Level of Dependence & .170 & $.180 \mathrm{H}_{2}$ Rejected \\
R(A)WU & .224 & $.047 \mathrm{H}_{4}$ Supported \\
Legislatif Size .226 .049 & & \\
\hline
\end{tabular}

Source: secondary data processed 2019

Regional wealth influences the level of RGFS disclosure, this condition shows that the local government/municipality government revenue that is sourced from local taxes, regional levies and other revenues is quite large. The greater community contribution through taxes and levies will be followed by a high concern for the management of LOR, thus demanding that local governments be more accountable and transparent for the realization and utilization of LOR that they have collected (Setyaningrum \& Syafitri, 2012). This encourages regional governments to present and disclose financial statements better and comprehensively according to Government Accounting Standards (GAS). This finding is in line with Setyaningrum and Syafitri (2012); Liestiani and Martani, 2012); Feriyanti et al. (2015); Hilmi and Martani (2012); and Cristiana and Maryono (2016) show that the level of regional wealth has a significant positive effect on the level of disclosure of provincial RGFS.Such conditions indicate the role of stewards and principals, that is, the regional government and the community are intertwined and well implemented. So that the wealth of this region can encourage local governments to make disclosures according to GAS. The amount of LOR realization shows the greater resources owned to finance government activities including the quality of the preparation of financial statements. Large financial resources will support financial reporting reliably including disclosures that are sufficient in accordance with GAS.

The level of dependency does not affect on the level of RGFS disclosure. Such conditions indicate a lack of monitoring from the central government. This happens because the central government allocates revenue sharing funds as a routine activity, so that it does not require special time for monitoring and evaluation. Lack of central government control over the use of transfer funds has caused the provincial government not to be encouraged to increase adequate RGFS disclosure (Ryan et al., 2002). If the use of regional transfer funds is not monitored properly. If the use of regional transfer funds is not monitored properly, then the regional government does not encourage to improve the quality of financial statements and the proper disclosures. This finding does not support the stewardship theory, provinces that have a high level of dependency will be more likely in an effort to increase transparency and accountability as steward responsibility through adequate disclosure of the use of transfer funds. However, in practice there is a lack of control and the supervision is still low which makes the regional government make disclosures that are not as they should be. Such conditions indicate the role of stewards and principals between regional governments and the government is not well implemented, so that there is no awareness of stewards in carrying out their responsibilities. This finding is in line with studies conducted by Hilmi and Martani (2012); Heriningsih and Rusherlistyani (2013); Khasanah and Rahardjo (2014); and Cristiana and Maryono (2016) that the level of disclosure had no significant effect on the level of RGFS disclosure.

Government size has a significant positive effect on the level of RGFS disclosure. Entities that have a large amount of assets will have greater management and administration responsibilities. More and more types of assets owned will require greater administration with a variety of methods, because each type of asset has a different way of management and administration. The management and administration of assets in the regional government is not good enough. This is indicated by the many problems and irregularities in the management of regional assets. Therefore, a large amount of assets becomes an obstacle in its presentation and disclosure. Thus, the greater the number of assets, the more difficult it will be to disclose financial statements in accordance with GAS (Fadzil \& Nyoto, 2012).

Provinces that have large total assets are more likely in an effort to increase transparency and accountability as steward accountability through better disclosure of large total assets (Khasanah \& Rahardjo, 2014). This condition shows the role of stewards and principals can be implemented well. The large value of assets makes the community as a principal, both directly and through RRC members who are representatives of the community, 
putting pressure on the government to be more transparent in disclosing assets according to GAS. Likewise from the local government as a steward, the large asset value motivates the responsibility for managing assets to the principal by making better disclosures. This finding is in line with Khasanah and Rahardjo (2014); and Cristiana and Maryono (2016) that total assets have a positive effect on the level of RGFS disclosure.

The number of $R(A) W U$ s has a significant positive effect on the level of RGFS disclosure. Provincial governments that have many $\mathrm{R}(\mathrm{A}) \mathrm{WU}$ tend to make broader disclosures. The more complex a government is in carrying out activities it will cause the greater the level of disclosure made. The more complex the government, the more disclosure is needed to help users of financial statements understand the complexity of the activities carried out by the government.Provinces that have a large number of $\mathrm{R}(\mathrm{A}) \mathrm{WU}$ can show their responsibilities through better disclosure. The role of stewards and principals between regional governments and the community has been carried out well, so that the large number of R(A)WUs can encourage regional governments to make disclosures according to GAS. The more the number of R(A)WUs, the more information that must be disclosed in the financial statements so as to increase the disclosure of RGFS. This finding corroborates Feriyanti et al. (2015) and Cristiana and Maryono (2016) that the number of R(A)WUs had a significant effect on the level of RGFS disclosure.

Legislative size affects the level of RGFS disclosure. The RRC as a community representative has a supervisory function, which is to control the running of the government and oversee the implementation and reporting of regional government financial information so that the government is more transparent and accountable. The real condition shows that the board members have relevant knowledge in financial reporting so that they can carry out the monitoring function that should be on the local government to be demanded to be more obedient in RGFS disclosure according to GAS. This finding is in line with Giligan and Matsusaka (2001); Suhardjanto and Yulianingtyas (2011); and Setyaningrum and Syafitri (2012) that RRC influences the level of RGFS disclosure.

\section{Conclusion}

The existence of RGFS disclosures that are still low shows the low compliance of local governments on Government Accounting Standards and thus is still far from the expectation to good goverment governance. However, from year to year began to show an increase, although this increase has not been significant enough. Such conditions demand that local governments must strive to continuously improve the quality of their financial statements.

From the results of the analysis and testing the researchers draw the following conclusions: regional wealth has a significant positive effect on the level of disclosure of provincial RGFS in Indonesia, the level of dependency does not affect the level of disclosure of provincial RGFS in Indonesia, government size has a significant positive effect on the level of disclosure of provincial RGFS in Indonesia, the number of R(A)WUs has a significant positive effect on the level of disclosure of provincial RGFS in Indonesia, and the legislative size has effects on the level of disclosure of provincial RGFS in Indonesia.

Based on the test results it was found that the average level of disclosure of District /Municipality Regional Government Financial Statements (RGFS) in the Province of 2016-2018 showed an increase. Such conditions have the meaning that the regional government must strive to continuously improve the quality of its financial statements.

Overall, the level of disclosure of provincial RGFS in Indonesia is still low, so it can be concluded that the regional government has not fully complied with GAS as evidenced by the average level of provincial disclosure in Indonesia of $53.9 \%$. This shows that the provision government has not fully disclosed the mandatory disclosure items in the provincial RGFS. Therefore, it is necessary to do rewards and punishments firmly so that local governments obey the rules and regulations that have been set. Knowledge possessed by the legislative body regarding regional financial reports is still limited so that in carrying out the monitoring function is not yet optimal. Need to improve coordination and better cooperation between government management parties, namely $R(A) W U$ in order to meet the principles of good governance.

Some weaknesses that exist in the results of this study are the low coefficient of determination is only $25.8 \%$ meaning that the research model only has limited ability to explain the variance of RGFS disclosure of $25.8 \%$. Not all regional governments make disclosures based on RGFS by referring to new Government Regulation. This study uses a disclosure index that is considered to have an equal weight, and inappropriate use of proxies results in inappropriate analysis of the results showing the performance of local governments.

Recommended for further research improvement, namely the need to use the level of disclosure required RGFS based on the latest GAS accrual basis that began to be applied by all local governments in 2015. Researchers then need to give weight to items disclosed in the financial statements.

Furthermore, the model analysis can be done with a panel method that can provide an overview from time to time on the performance of local governments and the trends of each local government through differences in LOR conditions, balancing funds and economic growth of each region so that they can provide better conclusions. 
The next stage can also be done by regional comparison based on the number of audit findings so that it can be analyzed the difference in the effect of the number of findings on the level of RGFS disclosure. The use of panel data will be able to capture differences between individuals and also be able to compare individual conditions between periods. Need to pay attention to the quality and characteristics of human resources specifically such as the head of the region or RGFS compiler, or based on the review of RGFS by the inspectorate.

\section{References}

Cristiana, I., \& Maryono. (2016). Faktor-faktor penentu tingkat pengungkapan laporan keuangan Pemerintah Propinsi Indonesia. Dinamika Akuntansi Keuangan dan Perbankan, 5(2), 188-202.

Dwirandra, A.A.N. (2008). Efektivitas dan kemandirian keuangan daerah otonom kabupaten/kota di Propinsi Bali Tahun 2002-2006. Jurnal Ilmiah Akuntansi dan Bisnis, 3(2), 1-21.

Fadzil, F. H., \& Nyoto, H. (2011). Fiscal decentralization after implementation of local government autonomy in Indonesia. World Review of Business Research, 1(2), 51-70.

Feriyanti, M., Hermanto, H., \& Suransi, N. K. (2015). Determinan kepatuhan pada ketentuan pengungkapan wajib laporan keuangan pemerintah daerah (studi pada kabupaten/kota di Provinsi Nusa Tenggara Barat). Jurnal Infestasi, 11(2), 171-185.

Fitri, S. A., (2011). Analisis tingkat pengungkapan laporan keuangan pemerintah daerah (studi eksploratif pada kabupaten/kota di Sumatera Barat). Fakultas Ekonomi Universitas Andalas.

Godfrey, J., Hodgson, A., Tarca, A., Hamilton, J., \& Holmes, S. (2010). Accounting Theory. (7th Edition). New Jersey: John Wiley \& Sons, Inc.

Gore, A. K. (2014). The effects of GAAP regulation and bond market interaction on local government disclosure. Journal of Accounting and Public Policy, 23(1), 23-52.

Hendriyani, R., \& Tahar, A. (2015). Analisis faktor-faktor yang mempengaruhi tingkat pengungkapan laporan keuangan pemerintah provinsi di Indonesia. Jurnal Bisnis dan Ekonomi, 22(1), 25-33.

Heriningsih, S., \& Marita, M. (2013). Pengaruh opini audit dan kinerja keuangan pemerintah daerah terhadap tingkat korupsi pemerintah daerah (studi empiris pada pemerintah kabupaten dan kota di pulau jawa). Jurnal Manajemen, Akuntansi dan Ekonomi Pembangunan, 11(1), 67-78.

Heriningsih, S., \& Rusherlistyani, R. (2013). Faktor-faktor yang mempengaruhi tingkat pengungkapan laporan keuangan pemerintah daerah. Jurnal Ekonomi dan Bisnis, 13(2), 11-19.

Hilmi, A.Z., \& Martani, D. (2012). Analisis faktor-faktor yang mempengaruhi tingkat pengungkapan laporan keuangan pemerintah provinsi. Simposium Nasional Akuntansi XV. Banjarmasin.

Khasanah, N.L., \& Rahardjo, S.N. (2014). Pengaruh karakteristik, kompleksitas, dan temuan audit terhadap tingkat pengungkapan laporan keuangan pemerintah daerah. Diponegoro Journal Accounting, 3(3), 1-11.

Liestiani, A., \& Martani, D. (2012). Disclosure in local government financial statements : the case of Indonesia. Global Review Accounting Finance, 3(1), 67-84.

Mahsum, M., Sulistyowati, F., \& Andre, H. (2006). Akuntansi sektor publik. BPFE Yogyakarta, Yogyakarta.

Mandasari, P. (2009). Pratices of mandatory disclosure compliance in Indonesian local goverment. Universitas Sebelas Maret.

Martani, D., \& Lestari, A. (2010). Local government financial statement disclosure in Indonesia. Annual Meeting and Conference Asian Academic Accounting Association. Thammasat Business School.

Martinsen, D. S. \& Jorgensen, T. B. (2010). Accountability as a differentiated value in supranational governance. The American Review of Public Administration, 40(6), 742-760.

Medynatul. (2017). Analisis tingkat pengungkapan laporan keuangan pemerintah daerah (studi empiris pada pemerintah kabupaten Tanah Datar, kota Padang Panjang dan kabupaten Lima Puluh Kota). Jurnal Akuntansi, 5(1), 1-10.

Munoz, L. A., \& Bolivar, M. P. (2015). Determining factors of transparancy and accountability in local goverments: a meta analystic study. Lex Localis - Journal of Local Self-Government, 13(2), 129-160. 
Mustikarini, W. A., \& Fitriasari, D. (2012). Pengaruh karakteristik pemerintah daerah dan temuan audit BPK terhadap kinerja pemerintah daerah kabupaen/kota di Indonesia tahun anggaran 2007. Simposium Nasional Akuntansi XV: Banjarmasin.

Patrick, P.A. (2007). The determinants of organizational innovativeness: the adoption of GASB 34 in Pennsylvania local government. The Pennsylvania State University, United States - Pennsylvania.

Pitman, M.K., \& Groff, J. E. (2004). Municipal financial reporting on the world wide web: a survey of financial data displayed on the official websites of the 100 largest U.S municipalities. Journal of Government Financial Management, 53(2), 20-29.

Prakosa, K. B. (2004). Analisa pengaruh dana alokasi umum (DAU) dan pendapatan asli daerah (PAD) terhadap prediksi belanja daerah (studi empirik di propinsi Jawa Tengah dan DIY. Jurnal Akuntansi dan Auditing Indonesia, 8(2), 101-118.

Ryan, S., Stanley, T., \& Nelson, M. (2002). Accountability disclosure by Queensland local government councils: 1997-1999. Financial Accountability \& Management, 18(3), 261-289. https://doi.org/10.1111/14680408.00153

Schillemans, T. (2013). The public accountability review. a meta-analysis of public accountability research in six academic disciplines. Working Paper, Utrecht University School of Governance.

Sekaran, U., \& Bougie, R. (2010). Research methods for business a skill-building approach (5th ed.). United Kingdom: John Wiley \& Sons Ltd.

Serrano-Cinca, C., Rueda-Tomás, M., \& Portillo-Tarragona, P. (2009). Factors influencing e-disclosure in local public administrations. Environment and Planning C: Government and Policy, 27(2), 355-378. https://doi.org/10.1068/c07116r

Setyaningrum, D., \& Syafitri, F. (2012). Analisis pengaruh karakteristik pemerintah daerah terhadap tingkat pengungkapan laporan keuangan. Jurnal Akuntansi dan Keuangan Indonesia, 9(2), 154-170. http://dx.doi.org/10.21002/jaki.2012.10.

Sudarsana, H. S., \& Rahardjo, S. N. (2013). Pengaruh karakteristik pemerintah daerah dan temuan audit BPK terhadap kinerja pemerintah daerah (studi pada pemerintah kabupaten/kota di Indonesia). Diponegoro Journal of Accounting, 2(4), 1-13.

Suhardjanto, D., \& Yulianingtyas, R. (2011). Pengaruh karakteristik pemerintah daerah terhadap kepatuhan pengungkapan wajib dalam laporan keuangan pemerintah daerah (studi empiris pada kabupaten/kota di Indonesia). Jurnal Akuntansi dan Auditing, 8(1), 30-42. https://doi.org/10.14710/jaa.8.1.30-42.

Suhardjanto, D., \& Lesmana, S. I. (2010). Pengaruh karakteristik pemerintah daerah terhadap tingkat pengungkapan wajib di Indonesia. Jurnal STIE Bank BPD Jateng, 6(2), 25-40.

Sumartono., \& Pasolo, M. R. (2019). The factors of financial report transparency in the regional government. Journal of Contemporary Accounting, 1(1), 11-25. https://doi.org/10.20885/jca.vol1.iss1.art2.

Waliyyani, G. M., \& Mahmud, A. (2015). Pengaruh karakteristik pemerintah terhadap tingkat pengungkapan laporan keuangan pemerintah daerah di Indonesia. Accounting Analysis Journal, 4(2), 1-8. https://doi.org/10.15294/aaj.v4i2.7815. 